\title{
Kompulsif Satın Alma Davranışına Genel Bir Bakış*
}

\author{
Asena Gizem Yigit ${ }^{a}$, Bekir Govdere $^{\mathrm{b}}$
}

Öz: Kompulsif tüketim davranışı, bireylerin kaygı, duygu-durum bozukluğu, depresyon, stres gibi durumlarda yaşamış olduğu gerginliği hafifletmek için yaptığı tüketimdir. Burada birey için önemli olan herhangi bir ürün veya hizmet edinmeden çok satın alma sürecinde yaşadığı haz duygusudur. Kompulsif tüketiciler satın alma süreciyle birlikte kısa süreli bir rahatlama yaşalarsa da sonrasında pişmanlık duygusuyla karşı karşıya kalmaktadırlar. Özellikle içinde bulunduğumuz ve sürekli değişen hayat koşulları, dijitalleşme, internet kullanımı, firmaların satış ve pazarlama stratejileri, kredi olanakları gibi hususların bu davranışı beslediği yönünde görüşler mevcuttur. Bu çalışmada kompulsif satın alma davranışının daha iyi anlaşılabilmesi ve sosyo-ekonomik boyutunun öneminin kavranabilmesi hedeflenmektedir. Bu amaçla, ayrıntılı bir literatür taraması yapılarak kompulsif satın alma davranışının özellikleri, nedenleri, demografisi, toplumlardaki yaygınlığı ve sonuçları üzerinde durulmuştur. Kompulsif satın alma çalışmalarının çok eski bir geçmişi yoktur ve alanda yapılan çalışmaların çoğu klinik alanla çerçevelenmiştir. Bu durum, araştırmaların sosyo-ekonomik boyutunun geride kalmasına sebebiyet vermiştir. Bu anlamda, çalışmanın hem akademik hem de toplumsal alana katkı yapması beklenmektedir.

\section{An Overview of Compulsive Buying Behavior}

Abstract: Compulsive buying behavior is the consumption made by individuals to alleviate the tension experienced in situations such as anxiety, mood disorders, depression, and stress. In here, what is important for the individual is the feeling of pleasure in the purchasing process rather than obtaining any product or service. Although compulsive consumers experience a short-term relief with the buying process, they then face a feeling of regret. However, later they face a feeling of regret. In addition, this behavior, which causes great financial problems, causes not only economic problems but also social and family problems. In particular, there are opinions that the constantly changing life conditions, digitalization, internet use, sales and marketing strategies of companies, and credit opportunities feed this behavior. In this study, it is aimed to better understand compulsive purchasing behavior and to grasp the importance of its socio-economic dimension. For this purpose, a detailed literature review was made and the characteristics, causes, demography, prevalence and consequences of compulsive buying behavior in societies were emphasized. Compulsive buying studies does not have a very long history, and most of the work done in the field has been framed by the clinical field. This situation caused the socio-economic dimension of the studies to lag behind. In this sense, the study is expected to contribute to both academic and social fields.

\author{
Anahtar Sözcükler: \\ Kompulsif Satın Alma, \\ Kompulsif Tüketim, \\ Davranışsal îktisat, Kompulsif \\ Tüketici, Aşırı Tüketim \\ Davranışı \\ JEL: D11, D91 \\ Geliş : : 17 Mart 2021 \\ Düzeltme : 17 Mayıs 2021 \\ Kabul : : 01 Haziran 2021 \\ Tür : Derleme
}

Keywords: Compulsive Buying, Compulsive Consumption, Behavioral Economics, Compulsive Consumer, Excessive Consumption Behavior

JEL: D11, D91 $\begin{array}{ll}\text { Received } & : 17 \text { March } 2021 \\ \text { Revised } & : 17 \text { May } 2021\end{array}$

Accepted : 01 June 2021

Type : Review

\footnotetext{
Cite this article as: Yigit, A. G., \& Govdere, B. (2021). Kompulsif satın alma davranışına genel bir bakış. Business and Economics Research Journal, 12(3), 717-730. http://dx.doi.org/10.20409/berj.2021.347

a Res. Asst., Suleyman Demirel University, Faculty of Economics and Administrative Sciences, Department of Finance and Banking, Isparta, Turkiye, asenayigit@sdu.edu.tr (ORCID: 0000-0002-9791-2211)

b Prof., PhD., Suleyman Demirel University, Faculty of Economics and Administrative Sciences, Department of Economics, Isparta, Turkiye, bekirgovdere@sdu.edu.tr (ORCID: 0000-0002-7923-2183)
} 


\section{Giriş}

iktisat literatürünün temel varsayımlardan biri olan "rasyonalite" kavramının zaman içinde birçok eleştiriye uğraması, beraberinde davranışsal yaklaşımların kendini daha fazla göstermesiyle sonuçlanmıştır. Buna göre her daim akılcı ve rasyonel kararlar verdiği kabul edilen karar birimlerinin zaman içinde yerini sınırlı rasyonel bireye bırakması, bu varsayım üzerine inşa edilen birçok teorinin de günümüzde geçerliliğinin sorgulanması anlamına gelmiştir. Özellikle tüketim teorisinin temel yapıtaşı olan ve davranışların tahmin edilmesini mümkün kılan rasyonellik ilkesi, karar mekanizmasının anlaşılması konusunda yetersiz kalmış ve bu durum birçok araştırmacı tarafından eleştiriye uğramıştır (Acar, 2008). Geleneksel iktisatta, bütçe kısıtı altında, sınırsız intiyaçlarını maksimum faydayla karşılamaya yönelik rasyonel kararlar veren birey (Hatırlı, 2017), zaman içindeki yerini her zaman doğru kararlar veremeyen ve hatta bilişsel yanılgılara düşmeye meyilli birey figürüne bırakmıştır. Özellikle 1957 yılında Herbert A. Simon'ın literatüre "sınırı rasyonellik" kavramını kazandırmasıyla davranışsal iktisat alanına yönelen ilgi artmış ve bireylerin tüketim karar mekanizmaları daha sık ele alınmaya başlanmıştır. Bu dönem itibariyle, tüketimin, satın alınan ürünler veya onların teorik faydasından çok, birey özelinde ne anlama geldiklerini anlamaya yönelik çalışmalar başlamıştır. Diğer bir ifadeyle, ürünlerin fonksiyonel faydası haricinde satın alma kararına sebep olan diğer faktörlerin de etkisi ele alınmaya başlanmıştır (Hirschman ve Holbrook, 1982). Bireylerin çoğu zaman mantık dışı olarak hareket edebilecekleri, stres, kaygı ve benzeri duygu-durumlarının etkisi altında kaldıkları, özellikle belirsizlik içeren durumlarda temel varsayımdan sapabilecekleri birçok çalışma ile kanıtlanmıştır (Kahneman ve Tversky, 1984; O’Guinn ve Faber, 1989; Lee ve Mysyk, 2004; Peng, Li, Miao, Feng ve Xiao, 2013). Benzer şekilde değişen ekonomik ve sosyal hayat koşulları, internetin yaygınlaşması, dijitalleşmenin hızlanması tüketim olgusunun da zaman içinde evrim geçirmesi olarak kendini göstermiştir. Bununla birlikte anormal tüketim davranışları da incelenmeye değer bir alan halini almıştır. Artık bireyler için ürün satın almak sadece ihtiyaç giderme gerekliliği için değil, sembolik tamamlama, haz yaşama isteği, stres giderme aracı olarak da kullanılmaya başlanmıştır. Hatta bazı dürtüsel tüketim biçimleri bağımlılık boyutunda ele alınmakta ve ekonominin multidisipliner boyutunu ve çalışma alanını oluşturmaktadır (Kacen ve Lee, 2002). Bu davranışlardan biri de kompulsif satın alma davranışıdır. Literatüre ilk olarak Faber, O'Guinn ve Krych (1987) tarafından kazandıılan kompulsif satın alma kavramı "olumsuz duygulara/olaylara yanıt niteliğinde ortaya çıkan, kronik olarak tekrarlayan, daha sonraki aşamalarda engellenmesinin zorlaştığı ve maddi-manevi zarara neden olan satın alımlardan biri" şeklinde tanımlanmaktadır (O'Guinn ve Faber, 1989: 156). Bu sebepten dolayı kompulsif tüketim sadece bir tıbbi vaka olarak değil, ekonomik ve sosyal bir olgu olarak da ele alınmalıdır (Lee ve Mysyk, 2004).

Bu çalışmada anormal tüketim davranışlarından biri olan kompulsif satın alma davranışııın özellikleri, ortaya çıkma sebepleri, temel tanı kriterleri, sonuçları, toplumlarda görülme sıklığı ve bu alanda yapılan çalışmalar detaylı olarak ele alınmıştır. Literatürde bu tüketim biçimiyle ilgili çalışmaların sayıca azlığı göz önüne alındığında, söz konusu çalışmanın hem akademik literatüre hem de toplumsal ve ekonomik farkındalığa katkı sağlaması beklenmektedir.

\section{Kompulsif Satın Alma Davranışına Teorik Yaklaşım}

\subsection{Kavramsal ve Teorik Çerçeve}

Tanımsal anlamda ilk olarak 1987 yılında literatüre kazandırılan kompulsif satın alma kavramı, 1900'lü yılların başında "oniomani" adıyla Kraepelin ve Bleuler tarafından ortaya konmuştur. Satın alma manisi olarak tanımlanan bu davranış, dürtü bozukluğu olarak değerlendirilmiş ve patolojik olarak incelenmeye başlanmıştır. Sonrasında ise bu davranış hem ekonomik hem toplumsal bir olgu halini alarak ayrıntılı şekilde ele alınmıştır. Temelinde stres, kaygı, duygu-durum bozuklukları gibi faktörlerin yer aldığı kompulsif tüketim, bu duyguların yaratmış olduğu baskıdan kaçmanın bir yolu olarak tanımlanmaktadır (Russell, 1979). Diğer bir ifadeyle "kaygının/sıkıntının azaltılması için kullanılan ve sonrasında kendini gösteren öğrenilmiş tepki"dir (Davison ve Neale 1986: 258). Mueller vd. (2011)'ne göre ise "satın alma" davranışının üzerindeki kontrolün çoğunlukla kaybedilmesi ve ihtiyaç duyulmayan ürünlerin aşırı biçimde satın alınmasıdır. Burada bireyin hissettiği temel güdü, bir ürünün elde edilmesinin haricinde o ürünün elde edilmesi sırasında yaşanan haz 
duygusudur. Dolayısıyla alınan haz bir nevi kaygı azaltma durumu olarak tanımlanmaktadır. Ancak bununla birlikte bireyler satın alma davranışı sonrasında pişmanlık duymakta, bu pişmanlık duygusu yeni bir kaygı durumu yaratarak "başka bir kaygı düzeyine" taşıyabilmektedir (Cho, Kwan ve Seo, 2008). Nitekim satın alma akabinde yaşanan bu pişmanlık duygusu depresyona dahi neden olabilmektedir. Benzer şekilde düşük özsaygı, aşırı yemek yeme, negatif duygulardan çıkış arayışı, aşırı cinsellik, kumar alışkanlığı, materyalizm ve takıntılı davranış türlerine olan yatkınlık kompulsif tüketimle paralel olarak ortaya çıkabilmektedir (Faber ve O'Guinn, 1992; Yurchisin ve Johnson, 2004). Alanda yapılan çalışmalar aile ilişkileri, dürtü bozuklukları, otokontrol eksikliği, biyolojik faktörler ve sosyal çevre gibi birçok faktörün kaygı durumunu tetikleyerek bu davranışın ortaya çıkabileceğini göstermiştir (Vallance, D'Astous ve Fortier, 1988; Edwards, 1993; Dittmar, 2005). Ayrıca kültür ögesi de kişilerin tüketim şekillerine yön veren önemli değişkenlerden biridir. Farklı kültürlerde yapılan kompulsif tüketim araştırmalarının farklı sonuçlar vermesi, kültürün de tüketim şekli üzerinde etkili olduğunun bir göstergesidir (Neuner, Raab ve Reisch, 2005; Leite ve Silva, 2016; Adamczyk, 2018).

Illk olarak satın alma manisi olarak tanımlanan bu kavram daha sonraki süreçte kompulsif tüketim, bağımlıık yaratan tüketim, alışverişkolizm, harcama birliği gibi kavramlarla da anılmaya başlanmıştır (Krueger, 1988; Elliot, 1994; Lejoyeux, Ades, Tassain ve Solomon, 1996; McElroy, Satlin, Pope, Keck ve Hudson, 1991; Dittmar, 2005; Lee ve Mysyk, 2004; Faber ve O'Guinn, 2008). Bunun iki nedeni vardır: Birincisi, bu davranışın tanımlanması sırasında kullanılan sözcüklerin eş anlamlı olması; ikincisi ise her araştırmacının çalışmasında farklı değişkenlere odaklanmasıdır. Ancak genel itibariyle en çok odaklanılan isim "kompulsif satın alma" şeklinde olmuştur. Zaman içinde elde edilen bulgular tıpkı tanımında olduğu gibi kompulsif satın alma davranışının görüldüğü bireylerin taşıması beklenen hususlar konusunda da fikir birliği oluşmasına zemin hazırlamıştır. Goldsmith ve McElroy (2000)'e göre bir bireyin kompulsif tüketici olarak tanımlanabilmesi için sahip olması gereken üç tanı kriteri vardır. Bunlar şunlardır: (a) Aşırı ve ansızın gelen satın alma davranışı ile sıklıkla uğraşmak, (b) satın alma eyleminde görülen dürtülerin ve davranışların maddimanevi sıkıntılara yol açması ve (c) yapılan aşırı tüketimin sadece anormal duygu değişimleri dönemlerinde gerçekleşmemiş olmasıdır (sürekliliğinin olması).

Bu veriler ışığında değişime uğrayan bir başka konu da araştırmalarda kullanılan yöntemleridir. Kompulsif tüketim çalışmalarında ilk olarak psikolojik faktörlere yönelim gösterildiğinden psikolojik modeller kullanılmış, sonrasında ise sosyo-ekonomik faktörlerin ele alınmaya başlanması yeni modellerin ortaya konulmasını zorunlu kılmıştır (Wicklund ve Gollwitzer, 1981). Ayrıca 2000'li yıllardan itibaren, yaşanan teknolojik gelişmelere bağlı olarak, kompulsif tüketimin açıklanmasında nöroekonomik yöntemler de kendini göstermeye başlamıştır. Buradaki temel amaç, tarama yöntemlerinin kullanılmasıyla beynin işleyişindeki kimyanın daha net ele alınmasıdır (Kellett ve Bolton, 2009; Ertelt, Marino ve Müller, 2011). Bununla birlikte nöroekonomi alanında zamanla elde edilen bulgular, geleneksel akıma bir meydan okumaya sebep olmuştur (Loewenstein, Rick ve Cohen, 2008). Ancak kompulsif tüketimin nöroekonomik yaklaşımla ele alınması sonucunda edinilen bulgular çok az sayıda çalışmaya dayanmakta olup bu durum literatürde bir açık yaratmaktadır (Raab, Elger, Neuner ve Weber, 2011; Lawrence, Ciorciari ve Kyrios, 2014; Kyrios vd., 2018). Oysa kompulsif tüketicilerin bu alanla birlikte ele alınmasının hem toplumsal hem de ekonomik açıdan önemli sonuçları olduğu ve bu sonuçlara dayanarak kamu kurumlarının nörolojik çalışmaları destekleyici politikalarını arttıracağı belirtilmektedir. Böylece literatürdeki homoeconomicus insan modelinin yerine bilimsel temeli daha sağlam ve gerçeğe daha yakın bir insan modeli benimsenecektir (Raab vd., 2011).

\subsection{Kompulsif Satın Alma Davranışına Neden Olan Faktörler}

Kompulsif tüketim, kendini her zaman kalıcı bir bağımlılık olarak göstermeyebilmektedir. Bazı zamanlarda bireyler geçici kompulsif tüketim özelliği de sergileyebilmektedirler. Bu anlamda kompulsif satın alma davranışının "aşııı" kısmına odaklanan çalışmalar, genellikle geçici kompulsif tüketim sergileyen bireyleri görmezden gelmiştir. Oysaki bu davranışa ait yakınlık veya durumsal öncüller her zaman aynı motivasyonlara bağlı olarak kendini göstermeyebilmektedirler. Dolayısıyla bu konunun mikro ölçekte ele alınması, ana motivasyonların ayrıntılı olarak incelenmesi; kompulsif tüketimin anlaşılması ve farklı kompulsif tüketici tipleri arasında ayrıma gidilebilmesi için önem arz etmektedir. Literatürde bu ayrıma gitmiş birçok çalışma 
mevcuttur. Kompulsif satın alma davranışını psikolojik ve kültürel-çevresel faktörler olarak inceleyen Valence vd. (1988)'in yanı sıra Faber (1992) ise biyopsikososyal modeli benimseyerek, bu davranışa neden olan faktörleri biyolojik, psikolojik ve sosyolojik olarak üçe ayırmıştır. DeSarbo ve Edwards (1996), yatkınlık faktörleri (kişisel faktörler), durumsal faktörler (çevresel faktörler) ve diğer faktörler olmak üzere üç kısımda incelerken; Eroğlu (2015) ise kompulsif tüketime neden olan faktörleri kişisel, aile ile ilgili, arkadaş ve toplum ile ticari çevre olarak ele almıştır. Çalışmalarda farklı başlıklandırma ve ayrıma gidilmesinin nedeni ise, her çalışmanın hipotezinin birbirinden farklı olmasıyla ilişkilidir. Ancak öz itibariyle değerlendirildiğinde aynı değişkenler üstünde bir fikir birliği oluşmuştur. Bu çalışmada söz konusu faktörler kişisel ve çevresel olmak üzere iki başlık altında, genel bir çerçevede ele alınacaktır.

\subsubsection{Kompulsif Satın Alma Davranıı̧ında Kişisel Faktörler}

Kompulsif tüketim literatüründe kişisel faktörlerin bu davranış üzerinde oldukça etkili olduğunu tespit eden birçok çalışma mevcuttur. Yapılan ilk çalışmalar depresyon, dürtü kontrol bozuklukları, aşırı yemek yeme, kaygı bozuklukları gibi psikolojik faktörlere odaklanmış olsa da daha sonraki çalışmalar kişisel faktörlerin daha geniş çaplı haritasını ortaya koymuşlardır (Faber, Christenson, Zwaan ve Mitchell, 1995; Lejoyeux vd., 1996; Yurchisin ve Johnson, 2004; Dittmar, 2004). Tamamen içsel motivasyonlardan kaynaklı olarak ortaya çıkan bu faktörler literatürde psikolojik veya patolojik faktörler isimleriyle de ele alınmıştır. Bu başlık altında ele alınan temel faktörleri benlik saygısı, materyalizm, kaygı ve depresyon, dürtüsellik, narsizm, öz tutarsızlıklar, biyolojik faktörler ve kişilik özellikleri oluşturmaktadır.

Bireyin kendisinde hissettiği eksikliği tamamlama çabası zaman zaman onu tüketime yöneltebilmektedir. "Kim olduğundan" çok "kim olmak istediği" durumu, diğer bir deyişle, bireyin kendi içindeki kimlik çatışması bireyin benlik saygısıyla ilişkilidir. Literatürde benlik saygısıyla kompulsif tüketim arasındaki ilişki birçok kez çalışıımış ve düşük benlik saygısına sahip olan bireylerde kompulsif satın alma davranışının çok sık görüldüğü tespit edilmiştir (O'Guinn ve Faber, 1989; Scherhorn, Reisch ve Raab, 1990; Faber 1992; Yurchisin ve Johnson, 2004). İnsanlarda yer alan dürtüler içinde en güçlülerinden biri olan benlik saygısının belirleyicisi ise bireylerin kendi içindeki muhakemesinin bir sonucu olarak ortaya çıkmaktadır (Korkmaz Devrani, 2018). Benlik saygısının bireylerde düşük olması, kendilerine saygı duymamaları ya da eksikliğini hissettiği fiziksel veya psikolojik durumları tamamlama/kapatma çabası bireyi takıntılı tüketim davranışlarına yöneltmektedir. Birey her ne kadar başlarda bir rahatlama hissediyor olsa da takıntılı hal alan tüketim çılgınlığı bir zaman sonra bağımlılık haline dönüşmektedir (Hanley ve Wilhelm, 1992). Bu durum aslında öz tutarsızlıkları da meydana getirmektedir (Srivasteva, Locke ve Bartol, 2001). Bireyin aslında olduğu kişi veya içinde bulunduğu durumla idealindeki kişi veya durum arasındaki tutarsızık anlamına gelen öz tutarsızlık durumu da kişiyi kompulsif tüketime yönlendiren kişisel bir faktördür (Higgins, 1987). Benzer şekilde materyalizme olan eğilim de bu davranışı tetikleyen faktörlerden biridir. Materyalizm, maddi intiyaçlara bağımlılık ve tamamen maddi şeylere dayalı bir yaşam veya görüş tarzı olarak tanımlanmaktadır (Richins ve Dawson, 1992). Materyalist değerlere sıkı sıkıya bağlı bireyler için tüketim, ideal olarak gördükleri benliğe ulaşma çabası olarak tanımlanır. Dolayısıyla bu bireyler zaman içinde kompulsif tüketim gibi faydacı olmayan tüketim şekillerine yönelirler (Dittmar, 2004). Kompulsif tüketim ile materyalizm arasındaki ilişkinin varlığını tespit eden birçok çalışma mevcuttur (O'Guinn ve Faber, 1989; DeSarbo ve Edwards, 1996; Eroğlu, 2016; Kaderli, Armağan ve Küçükkambak, 2017). Malezya'da yapılan bir başka çalışmada, materyalizm değişkeninin, para tutumunun güç prestiji ve kaygı boyutlarının kompulsif satın alma üzerinde önemli etkileri olduğu ortaya konmuştur (Onga, Lau ve Zainudin, 2021). Bununla birlikte öz tutarsızlık ile materyalizm arasında da güçlü bir ilişkinin varlığı ve her iki faktörün de kompulsif satın alma davranışııın öngörücüsü olduğu bulgulanmıştır (Dittmar, 2005). Bulguları destekleyen başka bir çalışma da Türkiye'deki üniversite öğrencileri üzerinde yapılmıştır. Çalışmanın bulguları, hedonistik ve materyalistik değerlerin kompulsif satın alma davranışı üzerinde pozitif bir etkisinin olduğunu göstermektedir (Eren, Eroğlu ve Hacıoğlu, 2012). Benzer şekilde, Ulusoy ve Öztürk (2019) yaptıkları çalışmada materyalizmin kompulsif tüketim üzerinde pozitif etki yarattı̆̆ını tespit etmişlerdir.

Materyalizm ile benzer şekilde narsizmde de bireyler, maddi şeylere anlam yükleyerek ideal benliğe ulaşma çabasına girerler ve bunun için de tüketime yönelebilmektedirler. Aşırı yüksek benlik saygısı ve düşük 
empati ile ilişkili olan narsizmin de kompulsif tüketim ile ilişkisi tespit edilmiştir. Narsist özellikler kişiyi kompulsif tüketime yönlendiren önemli faktörlerden biridir (Rose, 2007; Jung ve Yi 2014; Zerach, 2016). Buna karşlık özgüveni yüksek olan kişilerin ise kompulsif tüketim eğiliminin düşük olduğu gözlemlenmiştir (Zheng vd., 2020)

Kompulsif tüketime yönlendiren faktörlerden bir diğeri ise kaygı ve depresyon durumudur. Kaygı (anksiyete), psikolojide tanımlanması zor olan yersiz bir endişe halidir. Kaygı durumuyla birlikte bireyde sıklıkla terleme, huzursuzluk, midede boşluk hissi, boş yere dolanma hali de görülebilmektedir Depresyonda da benzer durumların bulunması, kaygı ile depresyon arasında bir ilişki bulunduğunu göstermektedir (Türkçapar, 2004). Kompulsif tüketimin genellikle huzursuzluk, sıkıntı, kaygı durumunu azaltmak ve olumsuz duygulardan kaçmak için yapıldığı düşünüldüğünde temelinde kaygı bozukluğu ve depresyonun olduğu görülmektedir. Nitekim bu ilişkiyi tespit eden birçok çalışma mevcuttur (O'Guinn ve Faber, 1989, Tamam, Diler ve Özpoyraz, 1998; Workman ve Paper, 2010). Bununla birlikte kompulsif satın alma davranışına sahip bireyler, satın alma öncesinde güçlü bir arzu ve denetlenmesi zor bir istek duyduklarını ve akabinde artan bir kaygı durumuyla karşılaştıklarını; ancak satın alma eyleminin bu durumları azalttığını belirtmektedirler (McElroy, Kick ve Philips. 1995). Bu durum aslında dürtüsellik ve otokontrol eksikliğini de işaret etmektedir. Çünkü dürtü bozukluğu, bireyin dürtülenmesi sonrasında alacağı hazzı engelleyememesi ve geciktirmede güçlük yaşaması anlamına gelmektedir. Yani otokontrolünün zayıf olmasıyla ilişkilidir. Dolayısıyla kompulsif tüketim de bir dürtü kontrol bozukluğu olarak nitelendirilmektedir (McElroy, Keck, Pope, Smith ve Strakowski, 1994).

Biyolojik faktörler ve kişilik özellikleri, kompulsif tüketime neden olan etmenler arasında en çok üstünde durulan nedenlerdir. Alanda yapılan çalışmalarda bu davranış türüyle biyolojik durumlar arasında ilişkiler tespit edilmiştir. Alkolizm, kumar bağımlılığı gibi faktörlerin yanı sıra aile öyküsü, hormonel faktörler ve beyin aktiviteleri gibi biyolojik nedenler de kompulsif-aşırı tüketici ayrımının yapılabilmesi bakımından ele alınmaya başlanmıştır. Buna göre, kompulsif tüketimin görüldüğü ailelerde ortak birtakım özelliklere ulaşıımıştır. Örneğin, bu tür tüketim yapan ailelerde ve akrabalarda ortak olarak duygu-durum bozuklukları, kaygı bozuklukları, madde ve alkol bağımlılığı gibi faktörlerin bulunduğu ortaya çıkmıştır (McElroy vd., 1994; Black, 2007). Benzer şekilde obezitenin de kompulsif tüketimin tetikleyicilerinden biri olduğu tespit edilmiştir (Donovan, 1988). Ayrıca bazı hormonların vücutta az salgılanması dürtü kontrol bozukluğuna sebep olmakta ve bu durum da tüketim kontrolsüzlüğünü ortaya çıkarmaktadır (Nathan ve Rolland, 1987). Yine kişilik özellikleri ise kişinin olay ve durumlara verdiği tepkileri içermesi bakımından tüketim alışkanlıklarına yansıyan bir faktör olarak görülmektedir (Hartson, 2012). Nitekim son yıllarda kişilik özellikleri ile kompulsif tüketim arasındaki ilişkileri inceleyen çok sayıda çalışma mevcuttur (Balabanis, 2001; Gohary ve Hanzaee, 2014; Fayez ve Labib, 2016; Yüce ve Kerse, 2018; Özhan ve Akkaya, 2018).

\subsubsection{Kompulsif Satın Alma Davranışında Çevresel Faktörler}

Çevresel faktörler, bireylerin doğrudan içsel motivasyonlarından kaynaklanmayan, aile, sosyal çevre, kültürel özellikler ve toplumsal hayatın getirdiği bazı değişimlerden kaynaklanan faktörler olarak ele alınmaktadır. Kompulsif satın alma davranışını etkileyen başlıca çevresel faktörler, aile ile ilgili faktörler ile kültürel faktörlerdir. Ancak bunların yanı sıra son zamanlarda hızla artan dijitalleşme hareketiyle ortaya çıkan yeni olanaklar da tüketim şekilleri üzerinde kendini göstermektedir.

Literatürde aile ile ilgili faktörler ile kompulsif tüketim arasındaki ilişkiyi inceleyen çalışmalar, genellikle bu satın alma davranışına sahip bireylerin aile öyküsünün de bulunduğuna işaret etmektedir. Özellikle kompulsif tüketim davranışının üç nesli etkileyebildiği ve genellikle anne soyunu takip eden bireylerde görüldüğü tespit edilmiştir (Black, Repertinger, Gaffney ve Gabel, 1998). Ayrıca benzer şekilde kompulsif tüketim yapan bireylerin ailelerinde alkol bağımlılı̆ı, kumar, anksiyete gibi durumlar görüldüğünü bulgulayan çalışmalar da mevcuttur (McElroy, Keck ve Phillips, 1995; Frost, Steketee ve Williams, 2002). Aile yapısı da tıpkı aile öyküsü gibi kompulsif tüketime etki eden faktörler arasındadır. Yapılan bir çalışmaya göre boşanmış ebeveynlere sahip çocuklar boşanmamış olanlara göre daha fazla kompulsif tüketime yatkındır (Rindfleisch, Burroughs ve Denton, 1997). Aile ile ilgili faktörlerle beraber toplumun politik, dini ve sosyal yapısı da tüketim şekilleri üzerinde etkili olan faktörlerdir. Örneğin, Batı’ya ait yaşam tarzının görüldüğü 
ekonomilerde kompulsif tüketimin arttığına dair görüşler bulunmakta iken (Neuner vd., 2005); dini değerlerine bağlı toplumlarda kompulsif tüketim gibi tüketim şekilleri, diğer ülkelere nazaran daha seyrek görülebilmektedir (Adamczyk, 2018). Ayrıca bireysellikten uzak olan kolektivist toplumlarda bireylerin katı kurallarla sosyal çevrelerine ve değerlerine bağlı olması kompulsif tüketim için caydırıcı bir durumdur (Kacen ve Lee, 2002). Tüm bunlar kompulsif tüketimi etkileyen kültürel faktörler çerçevesinde toplanmaktadır.

Kompulsif satın alma davranışını etkileyen en önemli unsurlardan biri de dijitalleşmeye bağlı olarak gelişen olanaklardır. İnternetin hayatımıza girmesi ve yoğun dijitalleşme ortamına bağı̆ olarak zaman ve mekân kavramının anlamlarının değişmesi, artık tüketicileri bulundukları her yerden istedikleri yere götürme özelliğine sahip bir alt yapı kurmaktadır. Bu bir taraftan büyük bir olanak olup, bir taraftan takıntılı tüketim davranışını sergileyen bireyler için aslında bir dezavantaj oluşturmaktadır. Özellikle firmalar tarafından uygulanan pazarlama stratejileri tüketicilerin daha fazla alım yapmaları adına bir istek yaratmaktadırlar (Liaw ve Le, 2017). Promosyonlar, kampanyalar gibi teşvik edici pazarlama unsurları bireyleri dürtüsel kadar almaya da sevk edebilmektedir. Ayrıca internette geçirilen süre veya internet bağımlılığı ile kompulsif tüketim arasında da ilişki mevcuttur (Armağan ve Temel, 2018; Yakın ve Aytekin, 2019). Bunların haricinde internet üzerinden yapılan alışverişlerdeki ödeme kolaylı̆̆ı, nakitsiz alışveriş/ kredi kartı kullanımı ve böylece kolay borçlanma seçeneklerinin ortaya çıkması kompulsif tüketimi tetikleyen unsurlardan biri olmasına sebebiyet vermiştir (Park ve Burns, 2005). Nitekim kredi kartı kullanımları ile kompulsif tüketim arasındaki ilişkiyi tespit eden çalışmalar bu durumu kanıtlar niteliktedir (Roberts ve Jones, 2001; Phau ve Woo, 2008; Kellet ve Bolton, 2009). Çünkü internetin sağladığı kolaylık, zaman-mekan kavramlarının ortadan kalkması, çevrimiçi mağaza kavramı bireylerdeki ödül beklentisini karşılamaktadır (Ko, Roh ve Lee, 2020).

\section{Literatürde Kompulsif Satın Alma Davranışı}

Kompulsiyonlarla ilgili ilk yayınının 1838 yılında Esquirol tarafından yapılmasının ardından birçok araştırmacı zaman içinde bu tanımı genişleterek literatüre katkıda bulunmuşlardır (Carr, 1974). Öncelikle kaygı bozukluğu-kompulsivite ilişkisine odaklanan çalışmalar 1934 yılında Lewis'in çalışmasından sonra farklı bir boyuta evrilmiş ve Freud ile kompulsif bozukluklar bir bütün olarak ele alınmaya başlanmıştır. Freud (1895)'un düşüncelerinden yola çıkan Carr (1974), kompulsiyonlarla ilgili ortaya ilk çıkışından itibaren çağdaş teorileşme sürecine kadar olan kısmını geniş bir çerçeve ile ele almış ve diğer çalışmalara ortam hazırlamıştır. Bu bilgilerden hareketle Faber, O'Guinn ve Krych (1987), kompulsif satın alma davranışını tanımlayarak, bu davranışa sahip olan bireyleri diğer bireylerden ayıran motivasyonlar üzerinde durmuşlardır. Akabinde yapılan çalışmalar, bu çalışmanın üzerine temellendirilmiştir (Faber ve O'Guinn 1988; O'Guinn ve Faber 1989; Valence vd., 1988; Hirschman, 1992).

Kompulsif tüketimin ölçümlenmesi ile ilgili ilk ölçek çalışması ise Valence, d'Astous ve Fortier (1988) tarafından gerçekleştirilmiş ve ortaya 13 maddelik bir Kompulsif Satın Alma Ölçeği çıkmıştır. Ölçeğin geliştirilmesi aşamasında kurulan modele göre kompulsif tüketimin temelinde kaygı olmak üzere aile, genetik yatkınlık, biyolojik ve fiziksel faktörler ile kültür değiş̧enleri vardır. 76 kişiyle yapılan araştırma sonucunda toplanan veriler göstermiştir ki kaygı bu bozukluğun hem nedeni hem de sonucudur. Benzer sonuçlara ulaşan Faber ve O'Guinn (1989) ise 14 soruluk yeni bir ölçek geliştirmişlerdir. Toplamda 671 kişiyle yapılan anketler sonucunda ise günümüzde hala yaygın olarak kullanılan bir tarama aracının literatüre kazandırımasını sağlamışlardır. Bu çalışmalardan sonraki literatüre temel oluşturan çalışmalar yine Faber ve O'Guinn tarafından yapılmıştır (O'Guinn ve Faber, 1989; Faber ve O'Guinn, 1992; Faber, 1992). Araştırmacılar, çalışmalarında kompulsif satın alma davranışının öncüllerini, temel tanı kriterlerini, özelliklerini ve etki eden potansiyel motivasyonları ele alarak sonraki çalışmalara zemin yaratmışlardır. Ayrıca kompulsif tüketim davranışına sahip bireylerin nüfusun \%1,1 ile \%5,9'unu oluşturduğunu savunmuşlardır. Ancak Schlosser, Black, Repertinger ve Freet (1994)'ne göre bu oran çok daha yüksek seviyelerde kendini göstermektedir. Tüm bu sebeplerle birlikte, özellikle Mental Bozuklukların Tanısal ve İstatistiksel El Kitabı (DSM)'de kompulsif satın alma davranışııı yer almaması akademik çalışmaları bu alana daha fazla yönlendirmiştir. Bu durum, bu davranışın bir bozukluk veya hastalıktan ziyade ekonomik ve sosyolojik açıdan da ele alınması gerektiği anlamına da gelmektedir (Dittmar, 2005). Bu görüşü tamamlayan çalışmaların varlığı ve tıbbi çalışmaların birbiriyle çelişkili sonuçlar ortaya koyması, bahsi geçen duruma kanıt olarak gösterilebilir (Benson ve 
Eisenach, 2013; Weinstein, Maraz, Griffiths, Lejoyeux ve Demetrovics, 2016; Moulding, Duong, Nedeljkovic ve Kyrios, 2017). Benzer şekilde bu davranışın tıbbileştirilmesini eleştiren bir başka çalışmada ise, bunu bir hastalık olarak ele almayı, toplumsal sorunların görmezden gelinmesi olarak yorumlanmıştır (Lee ve Mysyk, 2004). Daha açık bir ifadeyle, tıbbileştirme sonucunda odağın bireye kayması, bu davranışa sebep olan kredi seçenekleri, faiz oranları, para yönetimindeki eksiklik gibi toplumsal ve ekonomik sorunları göz ardı etmek anlamına gelmektedir. Bu yüzden bu sorunun bir ekonomik sorun olarak anlaşılması ve tespit edilmesi gerekmektedir. Bu anlamda, kompulsif satın alma davranışının ölçümlenmesi için geliştirilen ölçeklerden biri de Monahan, Black ve Gabel (1996)'ne aittir. Bu çalışmanın en önemli noktası ise bu davranışa tanı koymadaki başarısının yanı sıra şiddetini derecelendirmek üzere de tasarlanmış olmasıdır.

Kompulsif satın alma davranışına ait çalışmalarda, bu davranışın psikiyatrik eş tanı kriterleri demografik veriler ve diğer davranış türleri ile ilişkisine sık rastlanmaktadır. Daha önce bahsedilen psikiyatrik eş tanıların yanı sıra, aşırı yemek yeme, madde bağımlıı̆ı̆, aşırı cinsellik, istifçilik gibi davranışların kompulsif tüketim ile ilişkili olduğu tespit edilmiştir (Faber vd.,1995; Black vd., 1998; Roberts ve Tanner, 2000; Mueller vd., 2007; Faber ve O'Guinn, 2008). Bununla birlikte kompulsif tüketimle benlik saygısı arasında olumsuz; materyalizm ve sosyal statü değişkenleri ile olumlu bir ilişki tespit edilmiştir (Yurchisin ve Johnson, 2004). Benzer şekilde bireyin materyalizm, hedonizm, reklama karşı tutumunun artmasının kompulsif tüketimde olumlu etki yaptığı ortaya konulmuştur (Eroğlu, 2016; Korkmaz Devrani, 2018). Modaya karşı tutum ile kompulsif tüketim arasında ise artan kredi kartı kullanımı oranının dolaylı bir etkisi tespit edilmiştir (Park ve Burns, 2005). Yaş ile ilgili olarak görüş birliği bulunmamasına rağmen ortalama olarak 18-24 arası kabul edilmektedir (Schlosser vd., 1994; Yurchisin ve Johnson, 2004; Dittmar, 2005; Attmann-Tautmann ve Johnson, 2009). Cinsiyetlere göre dağılım ele alındığında ise birçok çalışmada kadınların erkeklere göre daha fazla kompulsif tüketim yaptıkları tespit edilmiştir (Faber ve O'Guinn, 1992; Schlosser vd., 1994; Türk, 2018). Türk tüketiciler örnekleminde gerçekleştirilen kompulsif satın alma davranışına yönelik bir çalışmada da benzer şekilde kadınların erkeklere nazaran daha fazla kompulsif tüketici oldukları bulgulanmıştır (Akagün Ergin, 2011). Ancak bununla birlikte farklı görüş savunan çalışmalar da mevcuttur. Örneğin, Hussain ve Bolari (2012), çalışmalarında yaş ve cinsiyet değişkenlerinin farklılık göstermediğini bulgulamışlardır. Manchiraju, Sadachar ve Ridgway (2016) ise literatürde genel kanının aksine erkeklerin, kadınlara nazaran daha fazla kompulsif tüketim yaptığını bulgulamıştır. Koran, Faber, Aboujaoude, Large ve Serpe (2006)'ne ait çalışmada ise iki cinsiyette de aynı oranda kompulsif tüketime rastlanmıştır. Benzer şekilde kompulsif satın alma davranışında cinsiyetler arasındaki farkın Y kuşağında ortaya çıkmasına rağmen, Z kuşağında bu farkın ortadan kalktığını tespit eden çalışmalar da mevcuttur (Yiğit ve Yiğit, 2020). Dittmar ve Drury (2000)'e göre alışverişin kadınlara etiketlenmiş olması ve sosyal temsiller nedeniyle bu durumun toplumlarda devam etmesi, tüketimin en çok kadınlar tarafından yapıldığı kanısını devam ettirecektir. Ancak 2000'li yıllardan itibaren kadın-erkek arasında kompulsif satın alma bakımından farksızlıkların bulgulanması, ayrı bir çalışma konusu olarak ele alınmalıdır.

Kompulsif tüketim ile kredi kartı kullanımı arasındaki ilişki ve diğer değişkenlerin üzerinde yaratmış olduğu dolaylı ilişkiler de araştırılan konular arasındadır. Phau ve Woo (2008), kredi kartı kullanımı ile kompulsif tüketim arasında pozitif bir ilişki tespit ederken, Wang ve Xiao (2009) da alışverişte kredi kartıyla ödeme yapan bireylerin daha fazla kompulsif tüketime sahip olduğunu bulgulamışlardır. Yine Kaderli, Armağan ve Küçükkambak (2017), çalışmalarında kredi kartına karşı tutumla kompulsif tüketim arasında diğer değişkenlere göre güçlü ve pozitif yönde bir ilişki tespit etmişlerdir. Benzer şekilde Korur ve Kimzan (2016) kompulsif satın alma davranışında, kontrolsüz kredi kartı kullanımının satın alma sonrası pişmanlık davranışında kısmi aracılık etkisinin olduğunu bulgulamışlardır. Özellikle $Y$ kuşağından sonra alışverişlerde kredi kartı kullanımının arttığı göz önüne alındığında (Wang, 2009), bu durumun günümüz kompulsif tüketimini arttıracağını beklemek yanlış olmayacaktır.

Moowen ve Spears (1999) ile başlayan kişilik özellikleri-kompulsif tüketim araştırmaları sonrasında da devam etmiştir. Literatürde en çok karşılaşılan Beş Faktör Kişilik Modeli baz alınarak yapılan bu çalışmaya göre kompulsif satın alma davranışı ile sorumluluk kişilik özelliği arasında negatif, uyumluluk ile pozitif bir ilişkiye sahiptir. Balabanis (2001) ise bu davranışla dışa dönüklük kişilik özelliği ile pozitif, uyumluluk ile negatif ilişkili tespit etmiştir. Bunun yanı sıra yapılan çalışmalarda sorumluluk, nevrotiklik ve açıklığın kompulsif 
tüketimi öngören özellikler olduğu; sorumluluk ve duygusal dengenin ise kompulsif tüketim üzerinde negatif yönde etkisi olduğu tespit edilmiştir (Gohary ve Hanzaee, 2014; Yüce ve Kerse, 2018). Sonuçlarla uyumlu olarak, Özhan ve Akkaya (2018), sorumluluğun kompulsif tüketimi negatif yönde; dışa dönüklüğün ise pozitif yönde etkilediğini tespit etmişlerdir.

Kompulsif satın alma davranışının ve belirleyici faktörlerinin daha iyi anlaşılabilmesi için, bu kararların alındığı merkezi sistemi bilmek çok önemlidir. Bu amaçla, gelişen teknolojinin de etkisiyle nörolojik çalışmalar başlamıştır. Ancak yapılan çalışmalar içinde nöroekonomik çalışmaların sayısı oldukça azdır. 2007 yılında Knutson, Rick, Wimmer, Prelec ve Loewenstein'nin çalışmasına kadar satın alma kararlarının nörobiyolojisiyle ilgili çalışmaya rastlanmamıştır. Bu çalışma tercih-fiyat ilişkisini nöral yönden inceleyerek, satın alma işleminin gerçekleşmesinde ortaya çıkan beyin aktivitelerinin fMRI (functional magnetic resonance imaging- işlevsel manyetik rezonans görüntüleme) ile incelemeye tabi tutması bakımından önem arz etmektedir. Plassmann, Kenning ve Ahlert (2007)'nin yapmış oldukları başka bir nöroekonomik çalışmada marka sadakati ile satın alma kararlarına odaklanılmıştır. 22 kişilik bir grubun satın alma kararları sırasındaki sinirsel aktivasyonları fMRI ile izlenmiş ve tüketim kararlarında marka sadakatinin itici bir güç olduğu ortaya konmuştur. Raab vd. (2011)'ne ait çalışmada ise doğrudan kompulsif satın alma davranışına sahip olan ve olmayan bireylerdeki nöral farklııklara odaklanıımıştır. 49 kadın denek üzerinde gerçek satın alma ortamı altında fMRı ile yapılan araştırmanın sonuçlarına göre kompulsif alıcı olan ve olmayan bireylerin nöral aktivitelerinin birbirinden farklı olduğu tespit edilmiştir. Ayrıca kompulsif tüketim yapan bireyler, diğerlerine oranla daha fazla ürün satın almışlardır. Görüldüğü üzere kompulsif tüketim yapan bireylerin satın alma kararı aşamasındaki beyin aktiviteleri diğerlerine nazaran daha farklı olmaktadır. Bu durum gelecek çalışmalar için de yol gösterici nitelikte olup, kompulsif satın alma davranışı üzerinde yapılan nöroekonomik çalışmaların azlığı, literatürde bir boşluk yaratmaktadır.

Kompulsif satın alma davranışı birçok araştırmacı tarafından 1990 'ı yıllardan itibaren çalışılmaya başlanmış olsa dahi henüz tam olgunluğa erişememiş birçok soruyu içinde barındırmaktadır. Ancak literatür incelendiğinde dikkat çeken bir husus toplumlardaki yaygınlığın gün geçtikçe artmaya başlamış olmasıdır. Bu durum her ne kadar kültürden kültüre farklııık gösteriyor olsa da genel kanı dünya çapında birçok ülkede ve önemli oranlarda bu sorundan muzdarip bir kitle bulunmaktadır. Örneğin Koran vd. (2006) çalışmalarında ABD'deki kompulsif satın alma davranışının yaygınlık oranını \%5,8 olarak bulgulamışlardır. Ancak daha genç nüfus üzerinde yapılan araştırmalarda bu oranının \%16'ya kadar yükselebileceği vurgulanmıştır (Hassay ve Smith, 1996). Birleşik Krallık'ta yapılan bir araştırma ise toplum içinde kompulsif tüketici oranını \%13,5 olarak tahmin etmektedir (Dittmar, 2005). Benzer şekilde Alman nüfusunun \%6,9'u kompulsif tüketim eğilimi göstermekte iken (Mueller vd., 2010); Polonya için bu oran 2010 yılında \%2,4 iken 2016 yılında \%4,4 şeklinde kendini göstermiştir (Adamczyk, 2018). Benzer şekilde Adamczyk vd. (2020)'nin yaptıkları başka bir çalışmada ise Polonya'daki kompulsif satın alma eğilimi \%3 olarak tespit edilmiştir. Araştırmacılar bu durumu Polonya nüfusunun \%86'sının Hristiyan olması ve Hristiyanlıkta israfın kabul edilmemesinden kaynaklandığı şeklinde yorumlamışlardır (Adamczyk, Capetillo-Ponce ve Szczygıielski, 2020). Ülkeler arasındaki farklılaşmanın en temel nedeni sosyo-kültürel faktörlerin ülkelere göre değişiklik göstermesidir. Ancak "tüketim toplumu" kavramı olgunlaştıkça kompulsif satın alma davranışının daha yüksek boyutlara ulaşma ihtimali yükselmektedir (Kellett ve Bolton, 2009). Bunun yanı sıra toplumlardaki aile yapısının bozulması ve uyum duygusunun azalması, kompulsif tüketim yapan kişileri, yalnızlık duygusunun verdiği sıkıntıyı geçici olarak hafifleten telafi edici bir davranış olarak görünen kompulsif tüketime yönlendirmektedir (Murali, Ray ve Shaffiullha, 2012).

\section{Sonuç}

Anormal tüketim davranışlarından biri olarak değerlendirilen ve kısmen dürtü kontrol bozukluğu olarak sınıflandırılan kompulsif satın alma davranışı, özellikle kaygı temelli ortaya çıkan bir tüketim türüdür. Kişinin faydacı tüketimin aksine intiyacı olmayan şeylere yönelmesi, diğer bir deyişle ne aldığı ile değil "alma süreci" ile ilgilenmesinin bir sonucu olarak maddi kayıplar ve borçlanmalarla sonuçlanabilmektedir. Bununla beraber kişinin sosyal hayattan izole olması veya akabinde yaşadığı ailevi problemler kişiyi depresyona 
sürükleyebilmektedir. Yapılan çalışmalar da depresyonun bu davranışın hem nedeni hem de bir sonucu niteliğinde olduğunu ve bireyin kısır bir döngü içine girdiğini göstermektedir.

Benlik saygısındaki azalma, kişinin kendinde fiziksel veya psikolojik olarak eksik gördüğü şeyleri tamamlama arzusu, materyalist değerlere bağlılığı, hedonik tüketime olan yatkınlığı, narsistlik derecesi, biyolojik ve kişisel faktörler olmak üzere birçok değişken tarafından şekillendirilen kompulsif satın alma davranışının en büyük belirleyicilerinden biri de kültürel ve ailevi faktörlerdir. Küresel anlamda maddi-manevi zarara yol açan bir davranış bozukluğu olarak görülen kompulsif tüketim, firmaların satış-pazarlama stratejileriyle de kendini besleyebilmektedir. Araştırmalarda, genel olarak, kadınların daha fazla kompulsif tüketim yaptıkları tespit edilmiş olmakla birlikte, son yıllarda yapılan araştırmalarda erkeklerin de en az kadınlar kadar kompulsif tüketime yöneldiğine dair bulgular görülmektedir. Özellikle internetin hayatımıza girmesi ve teknolojik gelişmelerin çok hızı şekilde yaşandığı günümüz dünyasında, artık alışveriş kavramının sadece bir "tık" kadar uzağında olduğumuz düşünüldüğünde, kompulsif tüketimin giderek artış göstereceğine ilişkin bir beklenti oluşmaktadır. Nitekim internet ve kredi kartı kullanım oranlarının artışına bağı olarak kompulsif satın alma davranışında da bir artış görülmesi bu öngörüyü destekler niteliktedir. Alışveriş olgusunun kadınların üzerinde etiketlenmiş olması, yapılan ilk çalışmalarda kadın ağırlıkı denek kullanımına neden olmuştur. Bu durum da beraberinde kompulsif satın alma kavramını kadınlarla bütünleştiren bir faktör olmuştur. Ancak toplumlarda değişen cinsiyet rolleri göz önüne alındığında, bu tüketim türünde farklılaşmaların ortadan kalkacağına ilişkin beklentinin olduğu görülmektedir. Türkiye' de yaklaşık son 20 yıldır çalışılan bu alanla ilgili daha fazla çalışmaya intiyaç bulunmaktadır. Özellikle teknolojik alanda yaşanan değişimle birlikte nöroekonomik yaklaşımların bugün birçok alanda olduğu gibi kompulsif tüketim araştırmalarında da kullanılmaya başlanması, bu davranışın nörobiyolojisinin kavranması, özelliklerinin ve tanı kriterlerinin ortaya konulması, sosyo-ekonomik boyutunda baş gösteren sorunların belirlenmesi ve oluşturulan politikalarda da etkisini gösterecektir.

\section{Beyan ve Açıklamalar (Declarations and Disclosures)}

Yazarların Etik Sorumlulukları (Ethical Responsibilities of Authors): Bu çalışmanın yazarları, araştırma ve yayın etiği ilkelerine uyduklarını kabul etmektedirler.

Çıkar Çatışması (Conflicts of Interest): Yazarlar tarafından herhangi bir çıkar çatışması beyan edilmemiştir.

Finansal Destek (Funding): Yazarlar, çalışmanın hazırlanması ve/veya yayınlanması sürecinde herhangi bir finansal destek almamışlardır.

Yazar Katkı Oranı (Author Contributions): Yazarlar, çalışmaya olan katkılarını şu şekilde beyan etmişlerdir: Kavramlaştırma ve çalışma dizaynı, A. G. Yiğit; verilerin toplanması, A. G. Yiğit; verilerin analizi ve sonuçların yorumlanması, A. G. Yiğit ve B. Gövdere; çalışmanın ilk/taslak halinin yazııması, A. G. Yiğit ve B. Gövdere; çalışmanın gözden geçirilmesi ve düzenlenmesi/düzeltilmesi, A. G. Yiğit ve B. Gövdere. Çalışmanın ilk ve son hali tüm yazarlar tarafından okunmuş ve onaylanmış olup, yazarlar çalışmalarıyla ilgili sorumluluğu kabul etmektedirler.

Intihal Denetimi (Plagiarism Checking): Bu çalışma, intihal tarama programı kullanılarak intihal taramasından geçirilmiştir.

(*) Ilave Açıklama (Additional Disclosure): Bu çalışma, Süleyman Demirel Üniversitesi Sosyal Bilimler Enstitüsü Iktisat Anabilim Dalında Prof. Dr. Bekir Gövdere danışmanlığında yürütülen Arş. Gör. Asena Gizem Yiğit'in doktora tez çalışmasından türetilmiştir. 


\section{Kaynaklar}

Acar, G. T. (2008). iktisadı değiştirmek: Neoklasik iktisada eleştirel bir yaklaşım. İstanbul: Iletişim Yayınları.

Adamczyk, G. (2018). Phenomenon of compensative and compulsive buying in Poland: A socio-economic study, Economic and Environmental Studies, 18(4), 1181-1199.

Adamczyk, G., Capetillo-Ponce, J., \& Szczygiielski, D. (2020). Compulsive buying in Poland. An empirical study of people married or in a stable relationship. Journal of Consumer Policy, 43, 593-610.

Akagün Ergin, E. (2011). Compulsive buying behavior tendencies: The case of Turkish consumers. Global Journal of Business Management, 5(2), 1-6.

Armağan, E., \& Temel, E. (2018). Türkiye'de online kompulsif alışveriş davranışı üzerine ampirik bir çalışma. Dokuz Eylül Üniversitesi Sosyal Bilimler Enstitüsü Dergisi, 20(4), 621-653.

Attmann-Trautmann, J., \& Johnson, T. W. (2009). Compulsive consumption behaviours: Investigating relationships among binge eating, compulsive clothing buying and fashion orientation. International Journal of Consumer Studies, 33, 267-273.

Balabanis, G. (2001). The relationship between lottery ticket and scratch-card buying behaviour, personality and other compulsive behaviours. Journal of Consumer Behaviour, 2(1), 7-22.

Benson, A. L., \& Eisenach, A. D. (2013) Stopping overshopping: An approach to the treatment of compulsive-buying disorder. Journal of Groups in Addiction and Recovery, 8(1), 3-24.

Black, D. W. (2007). A review of compulsive buying disorder. World Psychiatry, 6, 14-18.

Black, D. W., Repertinger, S., Gaffney, G. R., \& Gabel, J. (1998). Family history and psychiatric comorbidity in persons with compulsive buying: Preliminary findings. American Journal of Psychiatry, 155(7), 960-963.

Carr, A. T. (1974). Compulsive neurosis: A review of the literature. Psychological Bulletin, 81(5), 311-318.

Cho, H., Kwan, J., \& Seo, H. (2008). Compulsive shopping in parkinson's disease-a case report. Journal of Movement Disorders, 1(2), 97-100.

Davison, G. C., \& Neale, J. M. (1986). Abnormal psychology. New York: Wiley

Desarbo, W. S., \& Edwards, E. A. (1996). Typologies of compulsive buying behavior: A constrained clusterwise regression approach. Journal of Consumer Psychology, 5(3), 231-262.

Dittmar, H., \& Drury, J. (2000). Self-Image: Is it in the bag? A gualitative comparison between ordinary and excessive consumers. Journal of Economic Psychology, 21,109-142.

Dittmar, H. (2004). Understanding and diagnosing compulsive buying. (Ed.) R. H. Coombs, Handbook of addictive disorders: A practical guide to diagnosis and treatment (pp.411-451). New Jersey: John Wiley \& Sons.

Dittmar, H. (2005). A new look at "compulsive buying": Self-discrepancies and materialistic values as predictors of compulsive buying tendency. Journal of Social and Clinical Psychology, 24(6), 832-859.

Donovan, D. M. (1988). Assessment of addictive behaviors: Implications of an emerging biopsychosocial model. (Ed.) M. Donovan ve G. A. Marlatt, Assessment of addiction behaviors. New York: Guilford.

Edwards, E. A. (1993). Development of a new scale for measuring compulsive buying behaviour. Financial Counseling and Planning, 4, 67-85.

Elliott, R. (1994). Addictive consumption: Function and fragmentation in postmodernity. Journal of Consumer Policy, 17, 159-179.

Eren, S. S., Eroğlu, F., \& Hacıoğlu, G. (2012). Compulsive buying tendencies through materialistic and hedonic values among college students in Turkey. Social and Behavioral Sciences, 58, 1370-1377.

Eroğlu, F. (2015). Kompulsif satın alma eğiliminde kişisel faktörlerin, postmodern tüketim şekillerinin ve bir pazarlama çabası olarak reklamın rolü. İstanbul Üniversitesi Sosyal Bilimler Enstitüsü, Doktora Tezi, İstanbul.

Eroğlu, F. (2016). Kompulsif satın alma: Kişisel faktörler, postmodern tüketim şekilleri ve reklama karşı tutumun rolüne yönelik bir araştırma. Balıkesir Üniversitesi Sosyal Bilimler Enstitüsü Dergisi, 19(35), 253-282.

Ertelt, T. W, Marino, J. M., \& Mueller, A. (2011). Etiology of compulsive buying. (Ed.) A. Mueller, \& J. Mitchell, Compulsive buying clinical foundations and treatment (pp. 19-25). NewYork: Taylor \& Francis e-Library.

Faber, R. J., O'Guinn, T. C., \& Krych, R. (1987). Compulsive consumption. (Ed.) M. Wallendorf \& P. Anderson, Advances in consumer research (pp. 32-135). Provo, UT: Association for Consumer Research.

Faber, R. J., \& O'Guinn, T. C. (1988). Compulsive consumption and credit abuse. Journal of Consumer Policy, 11, 97-109. 
Faber, R. J., \& O'Guinn, T. C. (1989). Classifying compulsive consumers: Advances in the development of a diagnostic tool. Advances in Consumer Research, 16, 738-744.

Faber, R. J. (1992). Money changes everything compulsive buying from a biopsychosocial perspective. American Behavioal Scientist, 35(6), 809-819.

Faber, R. J., \& O'Guinn, T. C. (1992). A clinical screener for compulsive buying. Journal of Consumer Research, 19(3), 459469.

Faber, R. J., \& O'Guinn, T. C. (2008). Compulsive buying review and reflection. (Ed.) C.P. Haugtvdt, P.M Herr \& F.R. Kardes, Handbook of consumer psychology (pp. 1039-1056). Newyork: Taylor \& Francis.

Faber, R., Christenson, G., De Zwaan, M., \& Mitchell, J. (1995). Two forms of compulsive consumption: Comorbidity of compulsive buying and binge eating. Journal of Consumer Research, 22(3), 296-304.

Fayez, M., \& Labib, A. (2016). Investigating the effect of the "big five" personality dimensions on compulsive buying behavior of Egyptian consumers. Journal of Business and Retail Management Research, 10(3), 114-125.

Freud, S. (1895) Collected papers. Vol. 1. London: Hogarth, 1924'ten akt. Carr, A. T. (1974). compulsive neurosis: A review of the literature. Psychological Bulletin, 81(5), 312.

Frost, R. O., Steketee, G., \& Williams, L. (2002). Compulsive buying, compulsive hoarding, and obsessive-compulsive disorder. Behaviour Therapy, 33, 201-214.

Gohary, A., \& Hanzaee, K. H. (2014). Personality traits as predictors of shopping motivations and behaviors: A canonical correlation analysis. Arab Economics and Business Journal, 9, 166-174.

Goldsmith, T., \& Mcelroy, S. (2000). Compulsive buying: Associated disorders and drug treatment. (Ed.) A. L. Benson, I shop, therefore I am: Compulsive buying and the search for self (pp. 217-242). Northvale: Aronson Press.

Hanley, A., \& Wilhelm, M. S. (1992). Compulsive buying: An exploration into self-esteem and money attitudes. Journal of Economic Psychology, 13, 5-18.

Hartston, H. (2012). The case for compulsive shopping as an addiction. Journal of Psychoactive Drugs, 44(1), 64-67.

Hassay, D. N., \& Smith, M. C. (1996). Compulsive buying: An examination of the consumption motive. Psychology and Marketing, 13(8), 741-752.

Hatırlı, S. A. (2017). Mikroekonomi (5. Baskı). Ankara: Alter Yayıncılık.

Higgins, E. T. (1987). Self-discrepancy: A theory relating self to affect. Psychological Review, 94, 319-340.

Hirschman, E. (1992). The consciousness of addiction: Toward a general theory of compulsive consumption. The Journal of Consumer Research, 19(2), 155-179.

Hirschman, E. C., \& Holbrook, M. B. (1982). Hedonic consumption: Emerging concepts, methods and propositions. Journal of Marketing, 46(3), 92-101.

Hussain, A. H., \& Bolari, A. M. (2012). The use of high-speed internet as a platform for compulsive online buying: A case of study of post-graduate students in Malaysia. Journal of Society and Space, 8(7), 32-43.

Jung, J., \& Yi, S. (2014). Assessment of heterogeneity of compulsive buyers based on affective antecedents of buying lapses, Addiction Research and Theory, 22(1), 37-48.

Kacen, J. J., \& Lee, J. A. (2002). The influence of culture on consumer impulsive buying behavior. Journal of Consumer Psychology, 12(2), 163-176.

Kaderli, Y., Armağan, E. A., \& Küçükkambak, S. E. (2017). Y kuşağının kompulsif satın alma davranışına etki eden faktörler üzerine bir araştırma. İstanbul Üniversitesi İşletme Fakültesi Dergisi, 46(2), 188-210.

Kahneman, D., \& Tversky, A. (1984). Choices, values and frames. American Psychologist, 39(4), 341-350.

Kellett, S., \& Bolton, J. V. (2009). Compulsive buying: A cognitive-behavioural model. Clinical Psychology and Psychotherapy, 16(2), 83-99.

Knutson, B., Rick, S., Wimmer, G. E., Prelec, D., \& Loewenstein, G. (2007). Neural predictors of purchases. Neuron, 53(1), 147-156.

Ko, Y. M., Roh, S., \& Lee, T. K. (2020). The association of problematic internet shopping with dissociation among South Korean internet users. International Journal of Environmental Research and Public Health, 17(9), 3235.

Koran, L. M., Faber, R. J., Aboujaoude, E., Large, M. D., \& Serpe, R. T. (2006). Estimated prevalence of compulsive buying behavior in the United States. The American Journal of Psychiatry, 163, 1806-1812.

Korkmaz Devrani, T. (2018). Durumsal benlik saygısının reklam izleme ile kompulsif satın alma ilişkisindeki düzenleyici etkisi. Sosyal Araştırmalar ve Davranış Bilimleri Dergisi, 4(5), 118-133. 
Korur, M. G., \& Kimzan, H. S. (2016). Kompulsif satın alma eğilimi ve alışveriş sonrası pişmanlık ilişkisinde kontrolsüz kredi kartı kullanımın rolü: AVM müşterileri üzerine bir araştırma. Tüketici ve Tüketim Araştırmaları Dergisi, 8(1), 43-71.

Krueger, D. W. (1988). On compulsive shopping and spending: A psychodynamic inquiry. American Journal of Psychotherapy, 42(2), 574-584.

Kyrios, M., Trotzke, P., Lawrence, L., Fassnacht, D. B, Alı, K., Laskowski, N. M., \& Mueller, A. (2018). Behavioral neuroscience of buying-shopping disorder: A review. Current Behavioral Neuroscience Reports, 5, 263-270.

Lawrence, L. M., Ciorciari, J., \& Kyrios, M. (2014). Cognitive processes associated with compulsive buying behaviours and related eeg coherence. Psychiatry Research: Neuroimaging, 221, 97-103.

Lee, S., \& Mysyk, A. (2004). The medicalization of compulsive buying. Social Science and Medicine, 58, 1709-1718.

Leite, P. L., \& Silva, A. C. (2016). Psychiatric and socioeconomic aspects as possible predictors of compulsive buying behavior. Trends Psychiatry Psychother, 38(3), 141-146.

Lejoyeux, M., Ades, J., Tassain, V., \& Solomon, J. (1996). Phenomenology and psychopathology of unctrolled buying. American Journal of Psychiatry, 153(12), 1524-1529.

Liaw, S., \& Le, T. M. (2017). Under interruptive effects of rarity and mental accounting, whether the online purchase intention can still be enhanced even with higher search costs and perceived risk. International Journal of Business and Management, 12(8), 160-174.

Loewenstein, G., Rick, S., \& Cohen, J. D. (2008). Neuroeconomics. Annual Reviews Psychology, 59, 647-672.

Manchiraju, S., Sadachar, A., \& Ridgway, J. L. (2016). The compulsive online shopping scale (coss): Development and validation using panel data. International Journal of Mental Health Addiction, 15, 209-223.

Mcelroy, S. L., Keck, P. E., \& Philips, K. A. (1995). Kleptomania, compulsive buying and binge-eating disorder. The Journal of Clinical Psychiatry, 56(4), 14-26.

Mcelroy, S. L., Keck, P. E., Pope, H. G., Smith, J. M. R., \& Strakowski, S. M. (1994). Compulsive buying: A report of 20 cases. The Journal of Clinical Psychiatry, 55(6), 242-248.

Mcelroy, S. L., Satlin, A., Pope, H. G., Keck, P. E., \& Hudson, J. I. (1991). Treatment of compulsive shopping with antidepressants a report of three cases. Annals of Clinical Psychiatry, 3, 199-204.

Monahan, P., Black, D. W., \& Gabel, J. (1996). Reliability and validity of a scale to measure change in persons with compulsive buying. Psychiatry Research, 64, 59-67.

Moulding, R., Duong, A., Nedeljkovic, M., \& Kyrios, M. (2017). Do you think that money can buy happiness? A review of the role of mood, materialism, self, and cognitions in compulsive buying. Current Addiction Reports, 4, $254-261$.

Mowen, J. C., \& Spears, N. (1999). Understanding compulsive buying among college students: A hierarchical approach. Journal of Consumer Psychology, 8(4), 407-430.

Mueller, A., Claes, L., Mitchell, J. E., Faber, R. J., Fischer, J., \& Zwaan, M. (2011). Does compulsive buying differ between male and female students? Personality and Individual Differences, 50, 1309-1312.

Mueller, A., Mitchell, J. E., Crosby, R. D., Gefeller, O., Faber, R. J., Martin, A., Bleich, S., Glaesmer, H., Exner, C., \& Zwaan, M. (2010). Estimated prevalence of compulsive buying in Germany and its association with sociodemographic characteristics and depressive symptoms. Psychiatry Research, 180(2-3), 137-142.

Mueller, A., Mueller, U., Albert, P., Mertens, C., Silbermann, A., Mitchell, J. E., \& Zwaan, M. (2007). Hoarding in a compulsive buying sample. Behaviour Research and Therapy, 45(11), 2754-2763.

Murali, V., Ray, R., \& Shaffiullha, M. (2012). Shopping addiction. Advances in Psychiatric Treatment, 18, $263-269$.

Nathan, C., \& Rolland, Y. (1987). Pharmacological treatments that affect cns activity: Serotonin. Annals of The New York Academy of Sciences, 499, 277-296.

Neuner, M., Raab, G., \& Reisch, L. A. (2005). Compulsive buying in a maturing consumer society: An empirical re-enquiry. Journal of Economic Psychology, 28(4), 509-522.

O'guinn, T. C., \& Faber, R. J., (1989). Compulsive buying: A phenomenological exploration. Journal of Consumer Research, $16(2), 147-157$.

Onga, Z. Y., Laua, J. L., \& Zainudina, N. (2021). Money attitude, materialism and compulsive buying among Malaysian young adults. Management Science Letters, 11(2021), 281-290.

Özhan, Ş., \& Akkaya, D. T. (2018). Kişilik özelliklerinin kompülsif satın alma eğilimi üzerindeki etkisi. Anadolu Üniversitesi Sosyal Bilimler Dergisi, 18(4), 101-116. 
Park, H., \& Burns, L. D. (2005). Fashion orientation, credit card use and compulsive buying. Journal of Consumer Marketing, 22(3), 135-141.

Peng, J., Li, H., Miao, D., Feng, X., \& Xiao, W. (2013). Five different types of framing effects in medical situation: A preliminary exploration. Iranian Red Crescent Medical Journal, 15(2), 161-165.

Phau, I., \& Woo, C. (2008). Understanding compulsive buying tendencies among young Australians: The roles of money attitude and credit card usage. Journal of Marketing Intelligence and Planning, 5, 441-460.

Plassmann, H., Kenning, P., \& Ahlert, D. (2007). Why companies should make their customers happy: The neural correlates of customer loyalty. (Ed.) G. Fitzsimons \& V. Morwitz, NA-Advances in consumer research (vol.34) (pp.735-739). Mn: Association For Consumer Research.

Raab, G., Elger, C.E., Neuner, M., \& Weber, B. (2011). A neurological study of compulsive buying behaviour. Journal of Consumer Policy, 34, 401-413.

Richins, M., \& Dawson, S. (1992). Materialism as a consumer value: Measure development and validation. Journal of Consumer Research, 19, 303-316.

Rindflesich, A., Burroughs, J. E., \& Denton, F. (1997). Family structure, materialism and compulsive consumption. Journal of Consumer Research, 23, 312-325.

Roberts, J. A., \& Tanner, J. F. (2000). Compulsive buying and risky behavior among adolescents. Psychological Reports, 86, 763-770.

Roberts, J., \& Jones, E. (2001), Money attitudes, creditcard use and compulsive buying among American college students. Journal of Consumer Affairs, 35(21), 213-40.

Rose, P. (2007). Mediators of the association between narcissism and compulsive buying: The roles of materialism and impulse control, psychology of addictive behaviors. Journal of The Society of Psychologists in Addictive Behaviors, 21(4), 576-581.

Russell, G. (1979). Bulimia nervousa: An ominous variant of anorexia nervousa. Psychological Medicine, 9, 429-448.

Scherhorn, G., Reisch, L. A., \& Raab, G. (1990), Addictive buying in West Germany: An empirical study. Journal of Consumer Policy, 13, 355-388.

Schlosser, S., Black, D. W., Repertinger, S., \& Freet, D. (1994). Compulsive buying: Demography, phenomenology, and comorbidity in 46 subjects. General Hospital Psychiatry, 16, 205-212.

Srivasteva, A., Locke, E., \& Bartol, K. M. (2001). Money and subjective well-being: It's not the money, it's the motives. Journal of Personality and Social Psychology, 80, 959-971.

Tamam, L., Diler, S. R., \& Özpoyraz, N. (1998). Kompulsif satın alma: Bir gözden geçirme. Türk Psikiyatri Dergisi, 9(3), 224-230.

Türk, Z. (2018). Kompulsif satın alma davranışının demografik özelliklere göre değerlendirilmesi: Görgül bir araştırma. işletme Araştırmaları Dergisi, 4(10), 1198-1216.

Türkçapar, H. (2004). Anksiyete bozukluğu ve depresyonun tanısal ilişkileri. Klinik Psikiyatri Ek 4, 12-16.

Ulusoy, E., \& Öztürk, A. (2019). Tüketicilerin moda ve materyalizm eğilimlerinin kompulsif satın almaya etkilerinin belirlenmesine yönelik bir araştırma. Selçuk Üniversitesi Sosyal Bilimler Meslek Yüksekokulu Dergisi, 22(2), 687703.

Valence, G., D'astous, A., \& Fortier, L. (1988). Compulsive buying: Concept and measurement. Journal of Consumer Policy, 11, 419-433.

Wang, C. L. (2009). Little emperors the future of China's consumer market. Young Consumers, 10(2), 95-97.

Wang, J., \& Xiao, J. J. (2009). Buying behavior, social support and credit card indebtedness of college students. International Journal of Consumer Studies, 33, 2-10.

Weinstein, A., Maraz, A., Griffiths, M. D., Lejoyeux, M., \& Demetrovics, Z. (2016). Compulsive buying- features and characteristics of addiction. (Ed.) V. Preedy, Neuropathology of drug addictions and substance misuse (vol. 3) (pp. 993-1007). UK: Academic Press.

Wicklund, R. A., \& Gollwitzer, P. M. (1981). Symbolic self-completion, attempted influence, and self-deprecation. Basic and Applied Social Psychology, 2(2), 89-114.

Workman, L., \& Paper, D. (2010). Compulsive buying: A theoretical framework. The Journal of Business Inquiry, 9(1), 89126.

Yakın, V., \& Aytekin, P. (2019). İnternet bağımlılığının online kompulsif ve online anlık satın alma davranışlarına etkisi. işletme Fakültesi Dergisi, 20(1), 199-222. 
Yurchisin, J., \& Johnson, K. K. P. (2004). Compulsive buying behavior and its relationship to perceived social status associated with buying, materialism, self-esteem, and apparel-product involvement. Family and Consumer Sciences Research Journal, 32(3), 291-314.

Yiğit, A. G., \& Yiğit, M. (2020). Kompulsif satın alma davranışının Y ve Z kuşaklarında cinsiyetler arası analizi. OPUS Uluslararası Toplum Araştırmaları Dergisi, 16(28), 1223-1240.

Yüce, A., \& Kerse, Y. (2018). Kişiliğin kompulsif satın alma davranışı üzerindeki etkisi: Ampirik bir çalışma. Atatürk Üniversitesi iktisadi ve Idari Bilimler Dergisi, 32(1), 143-156.

Zheng, Y., Yanga, X., Liua, Q., Chua, X., Huanga, Q., \& Zhoua, Z. (2020). Perceived stress and online compulsive buying among women: A moderated mediation model. Computers in Human Behavior, 103, 13-20.

Zerach, G. (2016). The mediating role of emptiness and materialism in the association between pathological narcissism and compulsive buying. International Journal of Mental Health and Addiction, 14, 424-437. 